\title{
Alteration of Macromolecular Synthesis and Membrane Permeability by a Streptococcus sanguis Bacteriocin
}

\author{
By R. SCHLEGEL AND H. D. SLADE \\ Department of Microbiology, Northwestern University Medical School, \\ Chicago, Illinois 6061 I, U.S.A.
}

(Received I5 October I973)

Although the elaboration of bacteriocins by streptococci has been described previously (Brock \& David, I963; Kuttner, I966; Kelstrup \& Gibbons, I969; Overturf \& Mortimer, I970; Kramer \& Brandis, I972), few attempts have been made to purify and characterize these bactericidal factors (Kramer \& Brandis, 1972). Streptococcus sanguis (strain Challis) produces a streptocin which is lethal for Streptococcus sanguis (strain Wicky) and can be purified by ammonium sulphate fractionation and Sephadex G-I oo column chromatography. We exposed sensitive strain Wicky cells to Challis streptocin and observed macromolecular synthesis and membrane permeability.

\section{METHODS}

The two streptococcal strains used in this study were obtained from the Central Public Health Laboratory, London, via Dr R. Pakula (Toronto). Challis streptocin, $\mathrm{STH}_{1}$, was prepared by Sephadex G-I00 chromatography of Challis culture filtrates and was purified 50 -fold relative to supernatant fluid protein. Details of this purification procedure as well as the methods for estimating streptocin titres have been described (Schlegel \& Slade, 1973).

Strain Wicky bacteria were grown in Brain Heart Infusion (BHI) medium until the extinction at $550 \mathrm{~nm}\left(E_{550}\right)$ was 0.30 . The culture was then diluted I : 100 with additional BHI medium. Samples $(2 \mathrm{ml})$ were dispensed into sterile test tubes containing $\left[{ }^{3} \mathrm{H}\right]$ thymidine ( $2.5 \mu \mathrm{Ci} / \mathrm{ml}$, I $5 \mathrm{Ci} / \mathrm{mmol}$ ), [ $\left.{ }^{3} \mathrm{H}\right]$ uracil (I $2.5 \mu \mathrm{Ci} / \mathrm{ml}, 7 \mathrm{Ci} / \mathrm{mmol}$ ), or $\left[{ }^{3} \mathrm{H}\right]$ leucine ( $2.5 \mu \mathrm{Ci} / \mathrm{ml}$, $25 \mathrm{Ci} / \mathrm{mmol}$ ) and incubated at $37{ }^{\circ} \mathrm{C}$ for $\mathrm{I} \cdot 0 \mathrm{~h}$. Purified streptocin, dissolved in $0.15 \mathrm{M}-\mathrm{NaCl}$ $+0.2 \mathrm{M}-\mathrm{KH}_{2} \mathrm{PO}_{4}$ (PBS, $\mathrm{pH} 7 \cdot 6$ ), was added to a final multiplicity of $\mathrm{I} \cdot 9$ streptocin 'molecules'/Wicky organism. Control cultures received equivalent volumes of PBS. At o, 5, 10, 20, 30 and $40 \mathrm{~min}$, Wicky cultures (experimental and control) were immersed in ice water and each filtered through a $0.45 \mu \mathrm{m}$ Millipore filter which had been pretreated with $3.0 \mathrm{ml} 5 \%$ $(\mathrm{w} / \mathrm{v})$ bovine serum albumin (BSA). Trapped Wicky bacteria were washed with $50 \mathrm{ml}$ saline and treated with $\mathrm{I} 5 \mathrm{ml}$ cold $10 \%$ trichloroacetic acid. The filters were dried and then counted in a Beckman LS-IO0 scintillation counter. Incorporation of radioactive precursor molecules into trichloroacetic acid-precipitable macromolecules was expressed as pmol ${ }^{3} \mathrm{H}$-labelled molecules/ml Wicky culture.

\section{RESULTS AND DISCUSSION}

Figure I $(a),(b)$ and $(c)$ shows that Challis streptocin inhibited DNA, RNA and protein synthesis in Wicky organisms. The dramatic inhibition of these three synthetic processes suggested that streptocin might possess a common site of action. According to Nomura's (1967) classical model, the streptocin might mediate alterations of membrane conformation 

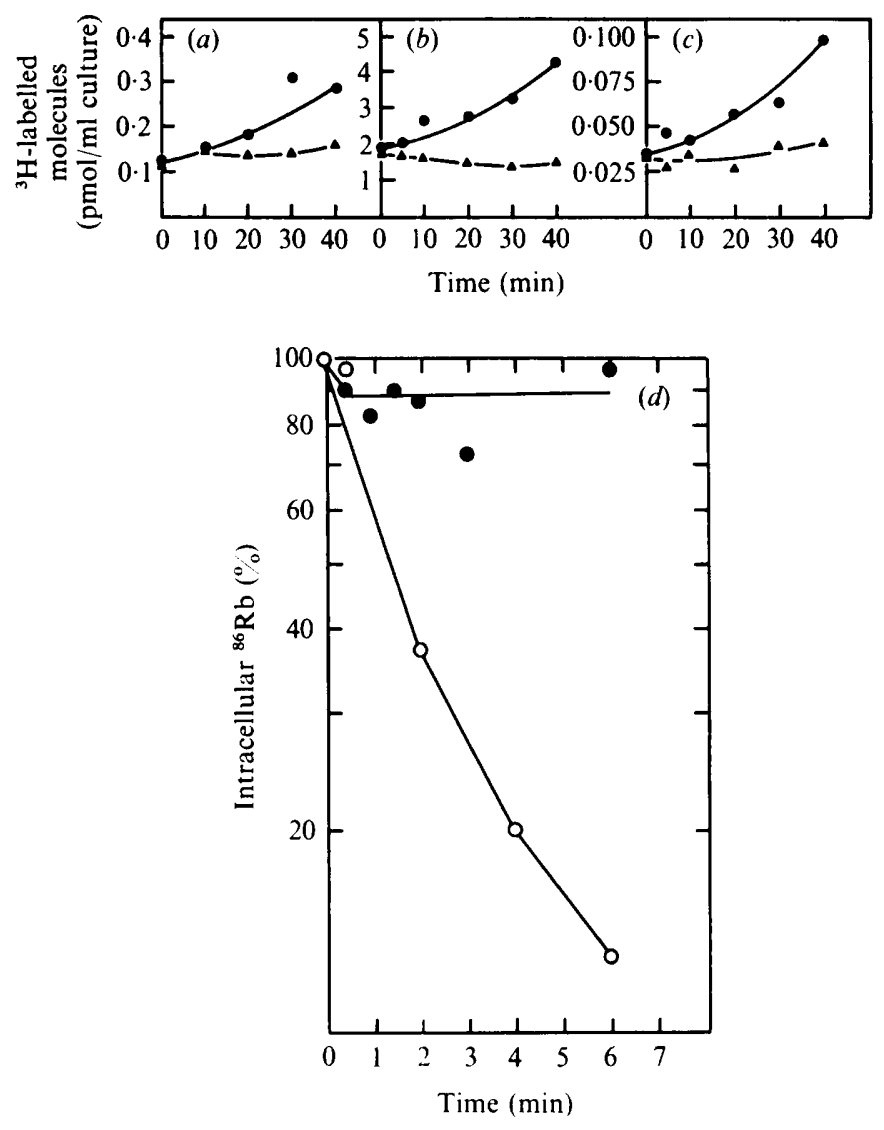

Fig. I. Inhibition of macromolecular synthesis by strain Challis bacteriocin $(a, b$, and $c)$. Strain Wicky organisms were pre-labelled with $12 \cdot 5 \mu \mathrm{Ci} / \mathrm{ml}$ of $\left[{ }^{3} \mathrm{H}\right]$ thymidine $(a),\left[{ }^{3} \mathrm{H}\right]$ uracil $(b)$, or $\left[{ }^{3} \mathrm{H}\right]$ leucine $(c)$. At o min, purified Challis streptocin was added to a multiplicity of $\mathrm{I} \cdot 9$ bacteriocin 'molecules'/ Wicky organism and estimates of subsequent macromolecular synthesis were obtained by trapping Wicky organisms on Millipore filters and measuring trichloracetic acid-insoluble radioactivity. $\boldsymbol{\Delta}$, Wicky organisms + streptocin; $\boldsymbol{O}$, Wicky organisms + PBS. (d) Release of ${ }^{86} \mathrm{Rb}$ from streptocintreated Wicky organisms. Strain Wicky cultures were pre-incubated with $100 \mu \mathrm{Ci}{ }^{86} \mathrm{Rb} / \mathrm{ml}$ for approximately $3 \mathrm{~h}$. Samples $(0.2 \mathrm{ml})$ were then inoculated into $\mathrm{I} \cdot 9 \mathrm{ml}$ PBS containing either streptocin $(\bigcirc)$ or heat-denatured streptocin $(O)$, multiplicity $=1 \cdot 6$. Intracellular ${ }^{86} \mathrm{Rb}$ was determined by filtering $0.2 \mathrm{ml}$ samples of suspension through a Millipore filter and washing with saline.

which could be translated into observable modifications of (i) energy production, (ii) membrane transport and permeability, or (iii) macromolecular synthesis.

A streptocin-induced change in the membrane permeability was therefore sought. In red blood cells (Hingson, Massengill \& Mayer, 1969) and bacterial cells (Wendt, 1970), membrane permeability to potassium $\left(\mathrm{K}^{+}\right)$ions can be studied by utilizing the radioactive ion, ${ }^{86} \mathrm{Rb}^{+}$, since $\mathrm{K}^{+}$and $\mathrm{Rb}^{+}$transport is competitive (Wendt, I970).

Wicky bacteria were grown in $3.0 \mathrm{ml}$ TM medium (Schlegel \& Slade, 1972) containing I00 $\mu \mathrm{Ci}^{86} \mathrm{Rb} / \mathrm{ml}$ to an $E_{550}$ value of $0 \cdot 20$. At this time, intracellular $\mathrm{Rb}^{+}$concentrations were more than Ioo times the extracellular $\mathrm{Rb}^{+}$concentrations. Samples $(0.2 \mathrm{ml})$ of the prelabelled Wicky bacteria were transferred to a test tube containing $\mathrm{I} \cdot 9 \mathrm{ml}$ purified streptocin or $\mathrm{I} \cdot 9 \mathrm{ml}$ streptocin denatured at $65{ }^{\circ} \mathrm{C}$ for $\mathrm{I} \cdot 0 \mathrm{~h}$. At intervals, $0.2 \mathrm{ml}$ samples were collected on $0.45 \mu \mathrm{m}$ Millipore filters which had been pretreated with $2.0 \mathrm{ml} 5 \% \mathrm{BSA}$ and $3.0 \mathrm{ml}$ 
saline $(0.85 \% \mathrm{NaCl}, \mathrm{w} / \mathrm{v})$. The filters were washed with $30 \mathrm{ml}$ saline, dried, and assayed for ${ }^{86} \mathrm{Rb}$ by counting on the ${ }^{32} \mathrm{P}$ channel of a Beckman LS- 100 scintillation counter. (The betaemitting energies of ${ }^{86} \mathrm{Rb}$ and ${ }^{32} \mathrm{P}$ are $\mathrm{I} \cdot 8$ and $\mathrm{I}^{\cdot} 7 \mathrm{MeV}$, respectively.) ${ }^{86} \mathrm{Rb}$ efflux from streptocin-treated Wicky bacteria was more rapid than the ion efflux from control bacteria (Fig. I $d$ ). This finding implies that the ability of the Wicky membrane to maintain high intracellular concentrations of ${ }^{86} \mathrm{Rb}$ has been affected. Whether this also reflects a change in the capacity of the membrane to retain other ions (e.g. $\mathrm{Mg}^{2+}$ and $\mathrm{Ca}^{2+}$ ) or small molecules (e.g. ATP, amino acids and sugars) is not known. However, it is possible that permeability changes resulting either in the loss of internal pools of precursor molecules for macromolecular synthesis or in the disturbance of essential intracellular ion concentrations might be responsible for the inhibition of synthesis observed in Fig. I $(a),(b)$ and $(c)$. Fig. I also indicates that the streptocin-treated bacteria apparently do not 'leak' macromolecules, which augments the previous finding (Schlegel \& Slade, I972) that sensitive bacteria are not lysed by the bactericidal factor. Thus, $\mathrm{Rb}^{+}$efflux is probably the result of subtle rather than gross membrane damage or alteration.

This investigation was supported by Public Health Service research grant HE-03709 from the National Heart and Lung Institute and by grants from the Office of Naval Research (NR-136-608), the Grainger Fund, and the Hemac Fund.

R.S. is a predoctoral trainee supported by Public Health Service general research support grant (I SO I Fr5370) from the National Institute of General Medical Sciences. H.D.S. is the recipient of Public Health Service research career award K6-GM 16284 from the National Institute of General Medical Sciences.

[REFERENCES

BRock, T. D. \& DAVIE, J. M. (I963). Probable identity of a group D hemolysin with a bacteriocine. Journal of Bacteriology 86, 708-7 I 2.

Hingson, D. J., Massengill, R. K. \& Mayer, M. M. (1969). The kinetics of release of 86-rubidium and hemoglobin from erythrocytes damaged by antibody and complement. Immunochemistry 6, 295-307.

Kelstrup, J. \& GibBons, R. J. (1969). Bacteriocins from human and rodent streptococci. Archives of Oral Biology $\mathrm{I}_{4}, 25 \mathrm{I}-258$.

KRAMER, J. \& BRANDIS, H. (i 972). Charakterisierung eines Streptococcus agalactiae bacteriocins. Zentralblatt für Bakteriologie, Parasitenkunde, Infektionskrankheiten und Hygiene 219, 290-30I .

KutTNer, A. (1966). Production of bacteriocines by group A streptococci with special reference to the nephritogenic types. Journal of Experimental Medicine 124, 279-29I.

Nomura, M. (1967). Colicins and related bacteriocins. Annual Review of Microbiology 21, 257-284.

OVerturf, G. \& MorTimer, E. A. (1970). Studies on the relationship between the production of bacteriocines by group A streptococci and acute glomerulonephritis. Journal of Experimental Medicine 132, 694-70I.

Schlegel, R. \& Slade, H. D. (1972). Bacteriocin production by transformable group H streptococci. Journal of Bacteriology I12, 824-829.

Schlegel, R. \& Slade, H. D. (1973). Properties of a Streptococcus sanguis (group H) bacteriocin and its separation from the competence factor of transformation. Journal of Bacteriology II5, 655-66I.

WENDT, L. (1970). Mechanism of colicin action: early events. Journal of Bacteriology 104, 1236-124I. 